\title{
MOLECULAR ANALYSIS OF RING Y CHROMOSOME IN A 10-YEAR-OLD BOY WITH MIXED GONADAL DYSGENESIS AND GROWTH HORMONE DEFICIENCY
}

\author{
Milenkovic $\mathrm{T}^{1, *}$, Guc-Scekic $\mathrm{M}^{2}$, Zdravkovic $\mathrm{D}^{1,3}$, Topic $\mathrm{V}^{4}$, \\ Liehr $\mathrm{T}^{5}$, Joksic $\mathrm{G}^{6}$, Radivojevic $\mathrm{D}^{2}$, Lakic $\mathrm{N}^{2}$
}

*Corresponding Author: Tatjana Milenkovic, Department of Endocrinology, Institute for Mother and Child Healthcare of Serbia “Dr. Vukan Cupic," Radoja Dakica 6-8, 11070 Belgrade, Serbia; Tel.: +381-11-3018-109; Fax:+381-11-3108-257; E-mail: tanjamil@eunet.rs

\begin{abstract}
Ring Y chromosome is a very rare chromosomal aberration. The published mixed gonadal dysgenesis (MGD) patients with a ring Y chromosome are short in stature, but are not growth hormone (GH) deficient. We present the molecular cytogenetic and molecular characterization of ring Y chromosome mosaicism in a 10-year-old boy with MGD whose short stature could be explained by the high percentage of cells monosomic for the X-chromosome, but also by the presence of severe GH deficiency. The ring Y chromosome in our patient is a de novo structural aberration. The father's karyotype was normal.
\end{abstract}

Key words: Growth hormone (GH) deficiency; Mixed gonadal dysgenesis (MGD); Mosaicism; Ring Y chromosome.

\section{INTRODUCTION}

The frequency of ring chromosomes in clinically detectable conceptions is $1 / 25,000$ [1]. Several mechanisms have been proposed for the formation of

\footnotetext{
Department of Endocrinology, Institute for Mother and Child Healthcare of Serbia "Dr Vukan Cupic", Belgrade, Serbia

2 Laboratory of Medical Genetics, Institute for Mother and Child Healthcare of Serbia "Dr Vukan Cupic", Belgrade, Serbia School of Medicine, University of Belgrade, Belgrade, Serbia

4 Department of Clinical Radiology, Institute for Mother and Child Healthcare of Serbia "Dr Vukan Cupic", Belgrade, Serbia

University Clinic Jena, Institute of Human Genetics, Jena, Germany

6 Vinca Institute of Nuclear Sciences, Belgrade, Serbia
}

ring chromosomes [2-4]. The most likely mechanism for their formation involves terminal breakage in both chromosome arms and fusion of the remaining ends and loss of deleted distal material. Because of the instability of ring chromosomes during mitosis, a second monosomic cell line is often present in these patients [4]. Most patients present a mosaic $45, \mathrm{X} / 46, \mathrm{X}, \mathrm{r}(\mathrm{Y})$ karyotype, with phenotypes ranging from female individuals with streak gonads to male patients with bilateral dysgenetic testes, mixed gonadal dysgenesis (MGD) or infertility as the only presentation [2,3,513]. Variability of phenotype depends on the percentage of monosomic cells and on the genetic material deleted during the formation of ring $\mathrm{Y}$ chromosome. There are few published reports in which ring the $\mathrm{Y}$ chromosome is directly associated with a MGD, but only exceptionally has the ring chromosome been analyzed by molecular techniques. These published MGD patients with a ring $\mathrm{Y}$ chromosome had short stature, but none of them had growth hormone (GH) deficiency $[2,12]$. Here, we present the molecular cytogenetic and molecular characterization of a ring $\mathrm{Y}$ chromosome mosaicism in a 10-year-old boy with MGD, short stature and GH deficiency.

\section{MATERIALS AND METHODS}

Clinical Report. A 10-year-old boy of healthy and unrelated parents was referred for evaluation of perineal hypospadias and unilateral cryptorchidism, anomalies that were incompletely surgically corrected 
in early childhood in a regional hospital. He was the second child in the family, born at term after a normal pregnancy and delivery: birth weight was $2850 \mathrm{~g}$ and length $49 \mathrm{~cm}$. His motor and mental development was normal. He was obese from early childhood. On admission to our hospital, his height was $129.3 \mathrm{~cm}$ (3rd10th centile), but inconsistent for the target height of $173.5 \mathrm{~cm}$ (25th-50th centile). His weight was 53.6 $\mathrm{kg}$, body mass index (BMI) was $32.99 \mathrm{~kg} / \mathrm{m}^{2}(>97 \mathrm{th}$ centile) and he had significant acanthosis nigricans on the neck, in the axillae and the cubital area. Bilateral pseudogynecomastia was also noticed. His external genitalia appeared predominantly male, his penis was $4.5 \mathrm{~cm}$, and showed scars from previous operations. The large scrotal sac contained a $4 \mathrm{ml}$ testis on the left, and an irregular mass of $0.5 \mathrm{ml}$ on the right.

Basal gonadotrophin levels were: luteinizing hormone (LH) $0.1 \mathrm{IU} / \mathrm{L}(0.03-0.43 \mathrm{IU} / \mathrm{L})$, follicle-stimulating hormone (FSH) $1.7 \mathrm{IU} / \mathrm{L}(0.22-1.92 \mathrm{IU} / \mathrm{L})$ and testosterone $0.1 \mathrm{nmol} / \mathrm{L}(0.06-0.8 \mathrm{nmol} / \mathrm{L})$. Testosterone response to a short human chorionic gonadotrophine (HCG) test showed 1.2 and $2.6 \mathrm{nmol} / \mathrm{L}$ on days 3 and 4 , respectively. Peak value of GH in the clonidine test was $1.2 \mathrm{mIU} / \mathrm{Ll}(>20 \mathrm{mIU} / \mathrm{L})$, while values during overnight profile of GH were as follows: for peak value $1.1 \mathrm{mIU} / \mathrm{L}$ $(>13.1 \mathrm{mIU} / \mathrm{L})$ and for mean value $0.23 \mathrm{mIU} / \mathrm{L}(>3.2$ $\mathrm{mIU} / \mathrm{L}$ ). The level of insulin-like growth factor-1 (IGF1) was $164 \mathrm{ng} / \mathrm{mL}(88-452 \mathrm{ng} / \mathrm{mL})$ and IGF binding protein-3 (IGFBP-3) was $4.9 \mu \mathrm{g} / \mathrm{mL}(2.1-7.7 \mu \mathrm{g} / \mathrm{mL}$ ). Serum free thyroxine and thyroid-stimulating hormone were normal. An oral glucose tolerance test showed no glucose intolerance but the insulin levels peaked at $656.8 \mathrm{mIU} / \mathrm{L}(100 \mathrm{mIUL} / \mathrm{L})$. The homeostasis model assessment of insulin resistance (HOMA-IR) was 6.6 (3.16). Levels of high density lipoprotein cholesterol (HDL-c), low-density lipoprotein cholesterorl (LDL-c) and triglycerides were normal. Bone age was estimated at 12 years. Magnetic resonance imaging (MRI) of the brain did not reveal any structural abnormality in the hypothalamic-pituitary region. Histopathology of surgical biopsy of the left gonad confirmed the presence of normal testicular tissue with early spermatogenesis. The irregular mass from the right side of the scrotal sac was histopathologically described as a streak gonad with the presence of a Fallopian tube and rudimentary uterus. Growth hormone therapy, $1.0 \mathrm{mg} / \mathrm{m}^{2} /$ day, was started. During the first year of treatment his height increased by $11.0 \mathrm{~cm}$ and reached the 25th centile. $\mathrm{He}$ remained extremely obese.
Cytogenetic and Molecular Cytogenetic Studies. Cytogenetic analysis was performed on G-banded metaphase chromosomes obtained from cultures of PHA-stimulated blood lymphocytes from the proband and his parents according to standard procedures $[14,15]$. Fluorescence in situ hybridization (FISH) was performed on peripheral blood lymphocytes using a Y chromosome cen satellite probe (Q-Biogene, Carlsbad, CA, USA) to detect and enumerate the Y chromosomespecific DYZ3 locus, according to the manufacturer's recommendations, using an Axioskop microscope and MC 80 camera (Carl Zeiss, Jena, Germany). Subcentromere-specific multicolor FISH (subcenM-FISH) was performed using RP11-115H13, RP11.71M14 and a centromeric probe for the $Y$ chromosome, as reported previously [16]. Fluorescent in situ hybridization with a subtelomeric TELVysion Xp/Yp probe, spectrum green (Abbott Laboratories, Abbott Park, IL, USA) and CEPY (DYZ1) probe for Yq12 (Abbott Laboratories) were used for precise characterization of the ring Y chromosome. The FISH images were captured on a Zeiss Axioplan microscope (Zeiss) with the IKAROS and ISIS digital FISH imaging system (MetaSystems, Altlussheim, Germany). Telomeric FISH (Telo-FISH) was performed as described in [17], using the Cy-3 labeled telomeric PNA probe (CCCTAA) 3 and staining with DAPI-mounting medium (Vector Laboratories). Chromosomal analysis was performed using a ZeissAxioimager A1 microscope equipped with a CCD camera and Axiocam image acquisition software (Imaging Associate) and software, Image J. Fifteen metaphases were analyzed for the presence of telomeric signals.

Molecular Genetic Studies. Genomic DNA was extracted from a peripheral blood sample by standard procedures [18]. The heterochromatic region of the $\mathrm{Y}$ chromosome was analyzed using polymerase chain reaction (PCR) with primers flanking part of a Y chromosome-specific region (the repetitive $3.4 \mathrm{~kb}$ sequence from the DYZ1 family) [19]. Diagnostic testing of Y chromosome-specific microdeletions was performed using multiplex PCR amplification directed against three distinct azoospermia $(A Z F)$ regions $[A Z F a$ (s84, s86), $A Z F b$ (s127, s134) and $A Z F c$ (s254, s255)] on the long arm of the $\mathrm{Y}$ chromosome, the $S R Y$ gene on the short arm of the $\mathrm{Y}$ chromosome, and the ZFX/ZFY gene as an internal control [20]. Positive and negative controls were provided by DNA samples from a man with normal spermatogenesis and from a healthy woman, respectively. 


\section{RESULTS}

Karyotype analysis of G-banded lymphocyte chromosomes revealed a 45,X karyotype in 24/44 (54.5\%) cells, a normal number of chromosomes with a small, dot-like ring chromosome in 17/44 (38.6\%) cells, and 47 chromosomes with two ring chromosomes (Figure $1 \mathrm{~A}$ and $1 \mathrm{~B})$ in $3 / 44(6.8 \%)$ cells. We considered the small ring chromosome to have originated from the $\mathrm{Y}$ chromosome and described the patient's karyotype as: $\operatorname{mos} 45, \mathrm{X}[24] / 46, \mathrm{X}, \mathrm{r}(? \mathrm{Y})[17] / 47, \mathrm{X}, \mathrm{r}(? \mathrm{Y}) \times 2[3]$. Parental karyotypes were normal. The C-banding analysis of the heterochromatic Yqh region of the patient and his father showed the loss of this region in the patient and its presence in the father, suggesting a de novo origin of the ring chromosome. Fluorescent in situ hybridization using a $\mathrm{Y}$ chromosome centromeric $\alpha$ satellite probe demonstrated the absence of a fluorescent signal in 31/100 cells and the presence of one $(19 / 100)$ and two $(2 / 100)$ fluorescent signals in interphase nuclei and metaphase cells (Figure 1C and 1D). When a $\mathrm{Y}$ chromosome centromeric $\alpha$ satellite probe was used, one fluorescent signal was found on the ring $\mathrm{Y}$ chromosome, confirming its monocentric nature. The somatic karyotype was therefore described as:
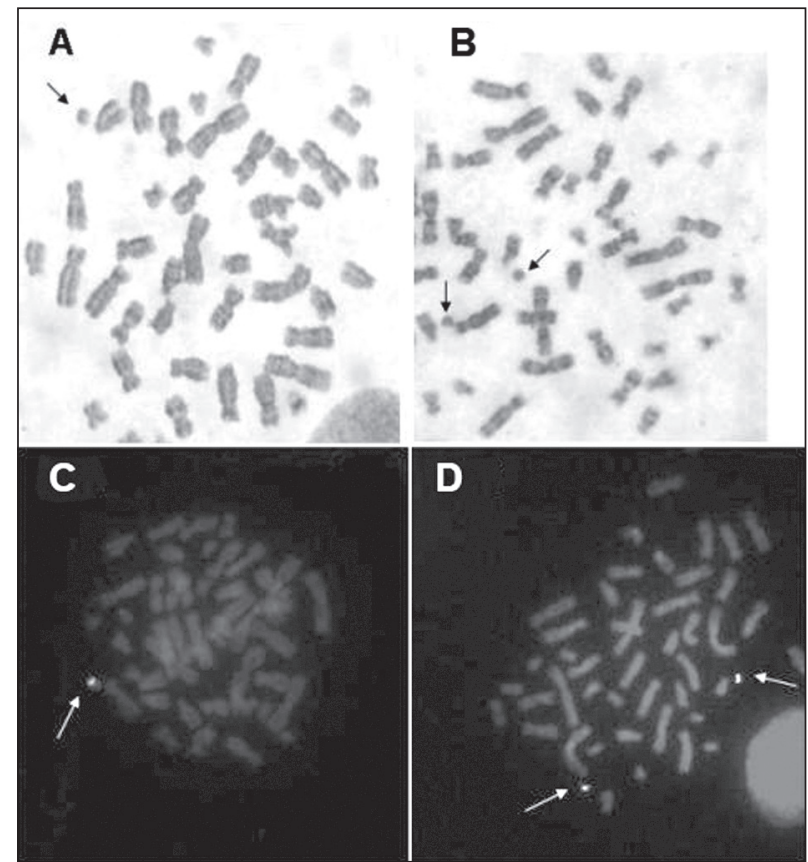

Figure 1. (A-B) G-Banded partial karyotype showing one and two ring $\mathrm{Y}$ chromosomes (arrow). (C-D) The FISH analysis with a Y-centromere satellite probe DYZ3 demonstrating one and two signals on metaphase chromosomes.

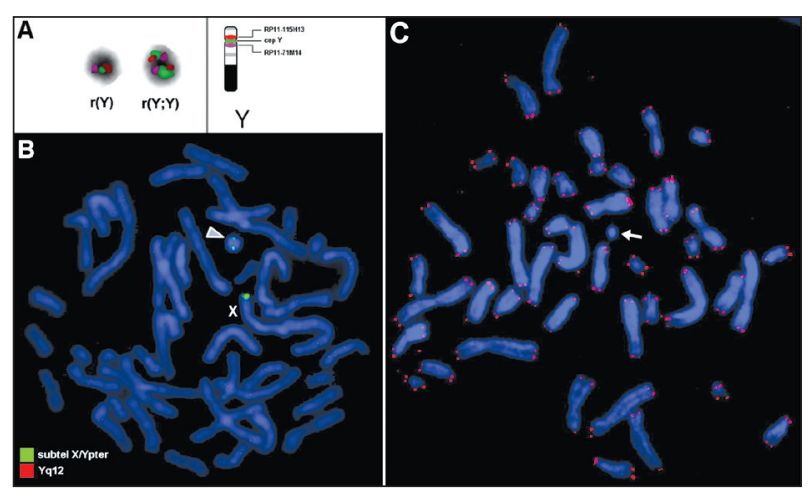

Figure 2.(A) SubcenM-FISH with probe set for the $\mathrm{Y}$ chromosome: ring $[\mathrm{r}(\mathrm{Y})]$ and double ring $[\mathrm{r}(\mathrm{Y} ; \mathrm{Y})]$ are shown on the left part of the figure. A scheme showing a normal Y chromosome and the probes applied is depicted on the right. (B) The FISH analysis with subtelomeric $\mathrm{Xp} / \mathrm{Yp}$ probe and probe for the Yq12 region demonstrates the presence of two signals on the double ring $[\mathrm{r}(\mathrm{Y} ; \mathrm{Y})]$ (arrow) and one signal on the normal X chromosome; the Yq12 signal is not present. (C) Telo-FISH displayed $\mathrm{r}(\mathrm{Y})$ chromosome with no telomeric signals (arrow).

45,X[31]/46,X.ishr(Y) (DYZ1+) [19]/ 47,X.ish r(Y) $\mathrm{x} 2(\mathrm{DYZ} 1 \times 2)[2]$.

SubcenM-FISH [25] characterized two $\operatorname{ring}(\mathrm{Y})$ variants in the patient's karyotype: ish $\mathrm{r}(\mathrm{Y})(\mathrm{RP} 11-$ 115H13+, cepY+,RP11.71M14+) and ishr(Y;Y)(RP11115H13++, cepY++,RP11.71M14++) (Figure 2A). These were present in different combinations in at least three cellular subpopulations: 46,X,r(Y);47,X,r(Y)x2; $47, \mathrm{X}, \mathrm{r}(\mathrm{Y})+\mathrm{r}(\mathrm{Y} ; \mathrm{Y})$. The additional ring $(\mathrm{Y} ; \mathrm{Y})$ variant, found in only one cell, was a ring chromosome in the process of forming a double ring.

Telo-FISH displayed an $\mathrm{r}(\mathrm{Y})$ chromosome with no telomeric signals (Figure 2C), thus confirming loss of telomeric regions on Yp and Yq. Fluorescent in situ hybridization with the subtelomeric probe $\mathrm{Xp} / \mathrm{Yp}$ and probe for Yq12, demonstrated the presence of the Yp subtelomeres and deletion of Yq12 region on the $r(Y)$. The double $\mathrm{Y}$ chromosome $\mathrm{r}(\mathrm{Y} ; \mathrm{Y})$ showed two signals for the Yp subtelomere region (Figure 2B).

Polymerase chain reaction with primers for the heterochromatic region of the $\mathrm{Y}$ chromosome revealed that the whole of this Yq12 region was missing. Multiplex PCR with selected primers for $A Z F$ (the $A Z F a$, $A Z F b$ and $A Z F c$ ) region, $S R Y$ and $Z F Y / Z F X$ genes showed their presence (Figure 3 ). These results confirmed the presence of two breakpoints on the $\mathrm{Y}$ chromosome that led to formation of the ring: one on the Yp arm (between the subtelomeric region and the telomere) and the other on the Yq arm at Yq12. 


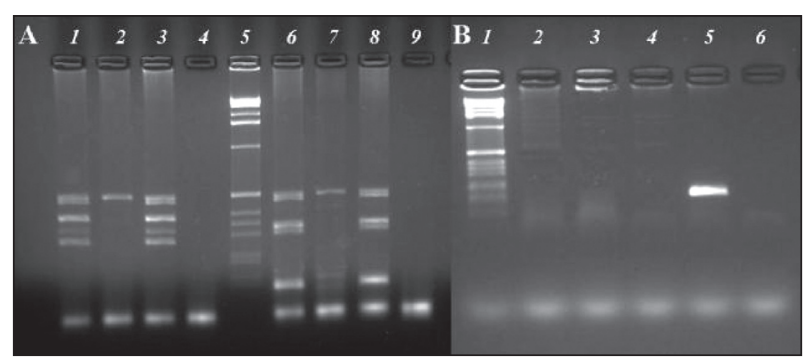

Figure 3. Polymerase chain reaction analysis. (A) Analyses of Y microdeletions (multiplex A and B); (B) detection of $\mathrm{Y}$ heterochromatin region; lanes 1 and $6(\mathrm{~A})$ and 2 and $3(\mathrm{~B})$ : the proband; lanes 2 and 7 (A) and 4 (B): female control; lanes 3 and 8 (A) and 5 (B): male control; lanes 5 (A) and 1 (B): $1 \mathrm{~kb}$ DNA ladder.

\section{DISCUSSION}

We present a male patient with MGD and a mosaic karyotype with a high percentage of monosomic 45,X cell line and two ring $(\mathrm{Y})$ variants presented in different combinations within at least three cellular subpopulations. Cytogenetic, molecular cytogenetic and molecular analyses demonstrated that the two breakpoints on the $\mathrm{Y}$ chromosome were localized on the Yp arm (between the subtelomeric region and the telomere) and the Yq arm at Yq12 (the AZF region was present), respectively, leading to fusion of the broken ends and loss of genetic material. As the father's karyotype is normal, ring formation occurred de novo in this patient. The presence of two $\operatorname{ring}(\mathrm{Y})$ variants, monocentric ring $\mathrm{Y}$ and dicentric ring $(\mathrm{Y} ; \mathrm{Y})$, could result from the specific behavior of the ring chromosome during mitosis depending on the number of sister chromatid exchanges (SCEs). These SCEs could result in the formation of dicentric $Y$ chromosomes, which would then undergo unequal partition during successive mitotic divisions inducing the formation of rings of different sizes $[4,21]$. Non disjunction could produce a general increase in the number of rings in different cellular populations, as was the case in our patient.

The high percentage of the monosomic $45, \mathrm{X}$ cell line in our patient, due to the instability of the ring chromosome during mitosis, could explain his short stature. The presence of subtelomere Yp signal on the $r(Y)$ chromosome suggests that the genetic material loss implicated in ring $\mathrm{Y}$ formation did not include the SHOX/PHOG gene, which is localized in the PAR1 region $[4,21,22]$. Molecular analysis showed the presence of the SRY gene. The dicentric ring $(\mathrm{Y} ; \mathrm{Y})$ found in one cell suggests the presence of a cell line with two copies of $S R Y$. More cells carrying the $S R Y$ gene result in more testicular structures and increased virilization due to higher production of testosterone by Leydig cells [2]. Bettio et al. [23] indicated that pheno-

Table 1. Clinical features of patients with a ring Y chromosome and mixed gonadal dysgenesis.

\begin{tabular}{|c|c|c|c|}
\hline Parameters & Our Patient & Patient in [12] & Patient in [3] \\
\hline Sex-Age & M-10 & M-12 & F-infant \\
\hline External genitalia & $\begin{array}{l}\text { Hypospadia, unilateral } \\
\text { cryptorchidism }\end{array}$ & $\begin{array}{l}\text { Hypospadia, unilateral } \\
\text { cryptorchidism }\end{array}$ & $\begin{array}{l}3 \times 1 \mathrm{~cm} \text { phallic structure, } \\
\text { perineal urethral opening, } \\
\text { bifid scrotum, single } \\
\text { urogenital opening }\end{array}$ \\
\hline $\begin{array}{l}\text { Karyotype from } \\
\text { peripheral blood }\end{array}$ & $\begin{array}{l}\text { 45,X/46,X,r(Y)/47,X,r(Y) } \\
\text { x2/47,X,r(Y)+r(Y;Y) }\end{array}$ & $\begin{array}{l}\text { 45,X/46,X,r(Y)/47,X,r(Y) } \\
\text { x2/48,X,r(Y)x3/49,X,r(Y)x4 }\end{array}$ & $\begin{array}{l}\text { 45,X/46,X,r(Y) (di-, tetra-, } \\
\text { octacentric) }\end{array}$ \\
\hline $\begin{array}{l}\text { Monosomic cells in } \\
\text { peripheral blood }\end{array}$ & $55.0 \%$ & $7.0 \%$ & $81.0 \%$ \\
\hline Molecular analysis & $\begin{array}{l}\mathrm{SRY}+\mathrm{AZF}(\mathrm{a}, \mathrm{b}, \mathrm{c})+ \\
\text { telomeres - subtelomeric } \\
\text { region: } \mathrm{p}+\mathrm{q}-\end{array}$ & $\begin{array}{l}\text { SRY }+ \text { (not in all ring } \mathrm{Y} \\
\text { chromosomes) }\end{array}$ & $\mathrm{SRY}+$ \\
\hline Father's karyotype & $46, X Y$ & 46,XYqh+ & No data \\
\hline Patient height & $5-10^{\text {th }}$ centile & $10^{\text {th }}$ centile & No data \\
\hline $\begin{array}{l}\text { Growth hormone } \\
\text { deficiency }\end{array}$ & Yes & No data & No data \\
\hline $\begin{array}{l}\text { Obesity and acanthosis } \\
\text { nigricans }\end{array}$ & Yes (weight: $>97^{\text {th }}$ centile) & Yes (weight: $90^{\text {th }}$ centile) & No data \\
\hline
\end{tabular}


typic sex is determined by the presence of the 45, X vs. $S R Y$-bearing cells and depends more on the number of copies of the $S R Y$ gene rather than on the percentage of 45 , $\mathrm{X}$ cells, at least in the gonads. The degree of mosaicism varies between tissues, and a mosaic karyotype is often associated with MGD [24].

Molecular analysis showed the presence of $A Z F$ $(A Z F a, A Z F b, A Z F c), S R Y$ and $Z F Y / Z F X$ genes that correlated with the pathological findings at testis biopsy, which revealed testicular tissue with initial spermatogenesis. Also, there was a normal testosterone response to a short HCG test.

According to the literature, the association of mixed gonadal dysgenesis and ring $\mathrm{Y}$ chromosome is extremely rare $[2,12]$. Our patient is the third patient with such abnormalities to be described in the literature. All patients have been short for their target height, but the two previous cases were not reported to have GH deficiency (Table 1). In our patient, the diagnosis of severe GH deficiency was established according to results of clonidine test as well as results of overnight profile of GH. Thus, he is the first reported case of gonadal dysgenesis associated with a ring $\mathrm{Y}$ chromosome whose short stature could be explained not only by the presence of a high percentage of monosomic cells, but also by GH deficiency. The first-year response to $\mathrm{GH}$ treatment with a standard dose of $\mathrm{GH}$ was successful. Normal levels of IGF-1 and IGFBP-3 could be explained by obesity, insulin resistance and hyperinsulinemia [25].

As with one patient reported previously [12], our patient was obese with significant acanthosis nigricans and pseudogynecomastia. His obesity was secondary to excessive food intake, consistent with the family's overall nutrition. Insulin resistance and acanthosis nigricans could be explaines as a common finding in obese children, as well as his advanced bone age. The obesity and acanthosis persisted after 1 year of $\mathrm{GH}$ therapy suggesting that the obesity at presentation was not a consequence of hypopituitarism.

Although short stature in patients with MGD associated with ring $\mathrm{Y}$ chromosomes can almost always be explained as a consequence of the high percentage of monosomic cells, or loss of SHOX and other genes important for growth, test for $\mathrm{GH}$ secretion should be performed in each child with impaired growth. Further studies are necessary to define the importance of provocative tests and/or overnight profile of $\mathrm{GH}$ in short patients with MGD.

\section{REFERENCES}

1. Jacobs PA. Mutation rates of structural chromosome rearrangements in man. Am J Hum Genet. 1981; 33(1): 44-54.

2. Henegariu O, Kernek S, Keating MA, Palmer CG, Heerema NA. PCR and FISH analysis of a ring Y chromosome. Am J Med Genet. 1997; 69(2): 171-176.

3. Henegariu O, Pescovitz OH, Vance GH, Verbrugge J, Heerema NA. A case with mosaic di-, tetra-, and octacentric ring Y chromosomes. Am J Med Genet. 1997; 71(4): 426-429.

4. Miller OJ, Therman E. Human Chromosomes. New York: Springer Verlag, 2001.

5. Hsu LY. Phenotype/karyotype correlations of Y chromosome aneuploidy with emphasis in structural aberrations in postnatally diagnosed cases. Am J Med Genet. 1994; 53(2): 108-140.

6. Sher ES, Addelston MB, Plotnick L, Urban MD, Berkovitz GD. Molecular investigation of two male subjects with short stature and a 45,X/46,X,ring(Y) karyotype. Horm Res. 1998; 49(1): 46-50.

7. Tanaka M, Ohmizono Y. Short stature and Turner skeletal features in an 11-year-old boy with a ring Y chromosome missing the short stature homeobox containing gene. Clin Pediatr Endocrinol. 2005; 14(2): 45-47.

8. Carvalho FM, Wolfgramm EV, Degasperi I, Verbeno BM, Vianna BA, Chagas FF, Perroni AMS, Paula F, Louro ID. Molecular cytogenetic analysis of a ring Y infertile male patient. Genet Mol Res. 2007; 6(1): 59-66.

9. Layman LC, Tho SPT, Clark AD, Kulharya A, McDonough PG. Phenotypic spectrum of $45, \mathrm{X} / 46, \mathrm{XY}$ males with a ring $\mathrm{Y}$ chromosome and bilaterally descended testes. Fertil Steril. 2009; 91(3): 791-797.

10. Liehr T, Mrasek K, Hinreiner S, Reich D, Ewers E, Bartels I, Seidel J, Emmanuil M, Petersen M, Polityko A, Dufke A, Iourov I, Trifonov V, Vermeesch J, Weise A. Small supernumerary marker chromosomes (sSMC) in patients with a karyotype $45, \mathrm{X} / 46, \mathrm{X},+$ mar -17 new cases and a review of the literature. Sex Dev. 2007; 1(1): 353-362.

11. Liehr, T. Homepage on small supernumerary marker chromosomes (sSMC). http://www.med.uni-jena. de/ fish/sSMC/ 00START.htm (Accessed March 15, 2011).

12. Lopez-Valdes JA, Nieto K, Najera N, Cervantes A, Kofman-Alfaro S, Queipo G. Mix gonadal dysgenesis associated with ring $\mathrm{Y}$ chromosome mosaics in a phenotypic male. Sex Dev. 2009; 3(4): 177-182.

13. Lee PA, Houk CP, Ahmed SF, Hughes IA. Consensus statement on management of intersex disorders. Pediatrics. 2006; 118(2): 488-500.

14. Moorhead PS, Nowell PC, Mellman WJ, Battips DM, Hungerford DA. Chromosome preparation of leukocytes cultured from human peripheral blood. Exp Cell Res. 1960; 20: 613-616. 
15. Seabright M. A rapid banding technique for human chromosomes. Lancet. 1971; 2(7731): 971-972.

16. Starke H, Nietzel A, Weise A, Heller A, Mrasek K, Belitz B, Kelbova C, Volleth M, Albrecht B, Mitulla B, Trappe R, Bartels I, Adilph S, Dufke A, Singer S, Stumm M, Wegner RD, Seidel J, Schmidt A, Kuechler A, Schreyer I, Claussen U, von Eggeling F, Liehr T. Small supernumerary marker chromosomes (SMCs): genotype-phenotype correlation and classification. Hum Genet. 2003; 114(1): 51-67.

17. Lansdorp PM, Verwoerd NP, van de Rijke FM, Dragowska V, Little MT, Dirks RW, Raap AK, Tanke HJ. Heterogeneity in telomere length of human chromosomes. Hum Mol Genet. 1996; 5(5): 685-691.

18. Miller SA, Dykes DD, Polesky HF. A simple salting out procedure for extracting DNA from human nucleated cells. Nucleic Acids Res. 1988; 16(3): 1215.

19. Kogan SC, Doherty M, Gitschier A. An improved method for prenatal diagnosis of genetic diseases by analysis of amplified DNA sequences. Application to hemophilia A. N Engl J Med. 1987; 317(16): 985-990.

20. Simoni M, Bakker E, Krausz C. EAA/EMQN best practice guidelines for molecular diagnosis of Y-chromo- somal microdeletions. State of art 2004. Int J Androl. 2004; 27(4): 240-249.

21. Arnedo N, Nogués C, Bosch M, Templado C. Mitotic and meiotic behavior of a naturally transmitted ring $\mathrm{Y}$ chromosome: reproductive risk evaluation. Hum Reprod. 2005; 20(2): 462-468.

22. Tyler Smith C. Chromosome Y: General and Special Features. Encyclopedia of Life Sciences. (John Wiley \& Sons, Ltd.) 2005 (www.els.net).

23. Bettio D, Venci A, Rizzi N, Negri L, Levi Setti P. Clinical and molecular cytogenetic studies in three infertile patients with mosaic rearranged $\mathrm{Y}$ chromosome Hum Reprod. 2006; 21(4): 972-975.

24. Quilter CR, Nathwani N, Conway GS, Stanhope R, Ralph D, Bahadur G, Serhal P, Taylor K, Delhanty JDA. A comparative study between infertile males and patients with Turner syndrome to determine the influence of sex chromosome mosaicism and the breakpoints of structural abnormal Y chromosomes on phenotypic sex. J Med Genet. 2002; 39(12): e80.

25. Juul A. Serum levels of insulin-like growth factor I and its binding proteins in health and disease. Growth Horm IGF Res. 2003; 13(4): 113-170. 